Article

\title{
Advantages of Using Microwave Satellite Soil Moisture over Gridded Precipitation Products and Land Surface Model Output in Assessing Regional Vegetation Water Availability and Growth Dynamics for a Lateral Inflow Receiving Landscape
}

\author{
Tiexi Chen ${ }^{1,2, *}$, Tim R. McVicar ${ }^{3,4}$, Guojie Wang ${ }^{1}$, Xing Chen ${ }^{2}$, Richard A. M. de Jeu ${ }^{5}$, \\ Yi Y. Liu ${ }^{4,6}$, Hong Shen ${ }^{7}$, Fangmin Zhang ${ }^{8}$ and Albertus J. Dolman ${ }^{9}$ \\ 1 Collaborative Innovation Center on Forecast and Evaluation of Meteorological Disaster, \\ School of Geography and Remote Sensing, Nanjing University of Information Science \& Technology, \\ Nanjing 210044, China; guojie.wang@vip.163.com \\ 2 School of Atmospheric Sciences, Nanjing University, Nanjing 210023, China; xchen@nju.edu.cn \\ 3 CSIRO Land and Water, GPO Box 1666, Canberra 2601, ACT, Australia; Tim.Mcvicar@csiro.au \\ 4 Australian Research Council Centre of Excellence for Climate System Science, Sydney, NSW 2052, Australia \\ VanderSat B.V., Huygensstraat 34, Noordwijk 2201 DK, The Netherlands; rdejeu@vandersat.com \\ 6 Climate Change Research Centre, University of New South Wales, Sydney, NSW 2052, Australia; \\ yi.liu@unsw.edu.au \\ 7 Department of Earth and Environmental Sciences, University of Michigan, Ann Arbor, MI 48109, USA; \\ hdshen@umich.edu \\ 8 Collaborative Innovation Center on Forecast and Evaluation of Meteorological Disasters, \\ College of Applied Meteorology, Nanjing University of Information Science and Technology, \\ Nanjing 210044, China; fmin.zhang@utoronto.ca \\ 9 Department of Earth Sciences, Faculty of Earth and Life Sciences, VU University Amsterdam, \\ Amsterdam 1081 HV, The Netherlands; han.dolman@vu.nl \\ * Correspondence: tiexi.chen@vip.163.com; Tel.: +86-25-5869-5687
}

Academic Editors: Magaly Koch and Prasad S. Thenkabail

Received: 6 March 2016; Accepted: 12 May 2016; Published: 20 May 2016

\begin{abstract}
To improve the understanding of water-vegetation relationships, direct comparative studies assessing the utility of satellite remotely sensed soil moisture, gridded precipitation products, and land surface model output are needed. A case study was investigated for a water-limited, lateral inflow receiving area in northeastern Australia during December 2008 to May 2009. In January 2009, monthly precipitation showed strong positive anomalies, which led to strong positive soil moisture anomalies. The precipitation anomalies disappeared within a month. In contrast, the soil moisture anomalies persisted for months. Positive anomalies of Normalized Difference Vegetation Index (NDVI) appeared in February, in response to water supply, and then persisted for several months. In addition to these temporal characteristics, the spatial patterns of NDVI anomalies were more similar to soil moisture patterns than to those of precipitation and land surface model output. The long memory of soil moisture mainly relates to the presence of clay-rich soils. Modeled soil moisture from four of five global land surface models failed to capture the memory length of soil moisture and all five models failed to present the influence of lateral inflow. This case study indicates that satellite-based soil moisture is a better predictor of vegetation water availability than precipitation in environments having a memory of several months and thus is able to persistently affect vegetation dynamics. These results illustrate the usefulness of satellite remotely sensed soil moisture in ecohydrology studies. This case study has the potential to be used as a benchmark for global land surface model evaluations. The advantages of using satellite remotely sensed soil moisture over gridded precipitation products are mainly expected in lateral-inflow and/or clay-rich regions worldwide.
\end{abstract}


Keywords: remote sensing; soil moisture; precipitation; NDVI; vegetation

\section{Introduction}

Improved knowledge of biosphere-atmosphere interactions is essential for understanding climate dynamics [1]. Water availability, temperature, and solar radiation are the main climatic constraints on terrestrial ecosystems, with water availability arguably the most important as it restricts about $50 \%$ of primary productivity of global terrestrial ecosystems [2,3]. While precipitation is considered to be the main contributor governing the variance of interannual vegetation activity in the temperate and boreal Eurasia [4] and the Sahel [5,6], soil moisture is more directly related to vegetation dynamics because it determines the water availability for vegetation $[7,8]$.

Since the late 1980s, remotely sensed data have been used to monitor large-scale vegetation conditions $[9,10]$ and several vegetation indices such as the Normalized Difference Vegetation Index (NDVI) are widely used for this purpose. Station and satellite observations of precipitation and NDVI, respectively, are often used to investigate the co-relationships between water availability and vegetation dynamics. For example, Wang et al. [11] found that the precipitation changes preceded those in NDVI by about two weeks to two months in the central Great Plains of the United States. Similar results were illustrated in Central Asia (1-3 months) [12] and in the Colorado River Basin (1-2 months) [13]. Additionally, the sensitivity of vegetation to precipitation is related to some precipitation thresholds. NDVI was found to be strongly sensitive to precipitation: (i) as long as precipitation did not exceed about $500 \mathrm{~mm} \cdot$ year $^{-1}$ or $50-100 \mathrm{~mm} \cdot \mathrm{month}^{-1}$ in semi-arid Botswana [14]; or (ii) when precipitation ranged from 100 to $400 \mathrm{~mm} \cdot$ year $^{-1}$ in Central Asia [12]. Vegetation may also be more sensitive to seasonally integrated precipitation rather than monthly integrals over global arid and semi-arid regions [15], and these relationships will change in water-limited areas as water use efficiency changes due to increased atmospheric $\mathrm{CO}_{2}$ concentrations [16].

Previous large-scale studies of water-vegetation relations relied mainly on one-dimensional modeled soil moisture or drought indices [7,17]. In the past decades, several algorithms to retrieve soil moisture from microwave satellite observations were developed and now surface soil moisture (i.e., the top few centimeters) is routinely observable from space [18-20]. A long-term remotely sensed surface soil moisture (usually not deeper than $5 \mathrm{~cm}$ ) dataset has been widely evaluated across the globe, showing favorable results when compared to isolated point-based soil moisture observations [21-24] and against models [25-27]. Additionally, significant positive relationships and coherent trends between NDVI and remote sensed soil moisture were shown over Australia [28].

Although theoretically soil moisture has a closer relationship to vegetation than precipitation, existing large-scale evidence still lacks the capability to demonstrate the differences between satellite remotely sensed soil moisture and precipitation in ecohydrological applications. In cases where lateral re-distribution of soil moisture occurs direct observation, not modeling, is preferable. Hence, in this paper, we provide direct evidence to answer the question "which of (i) remotely sensed soil moisture; (ii) gridded precipitation products; or (iii) land surface model outputs provides the optimal description of observed NDVI-based vegetation dynamics for a large regional inflow receiving landscape in northeastern Australia?"

\section{Materials and Methods}

\subsection{Study Area}

The study region is northeastern Australia (Figure 1), in which two sub-regions (denoted as REC and SQU) were selected for detailed investigation. To maximize the difference between the precipitation and soil moisture, the southern sub-region (SQU) lies in Australia's "channel country", a complex anastomosing river system with wide floodplain inundation (and subsequent vegetation 
growth) caused by lateral inflow following pluvial events in the headwaters (see Jarihani et al. [29,30] and the references therein). The topography is illustrated in Figure 1a using Global 30 Arc-Second Elevation (GTOPO30) [31].
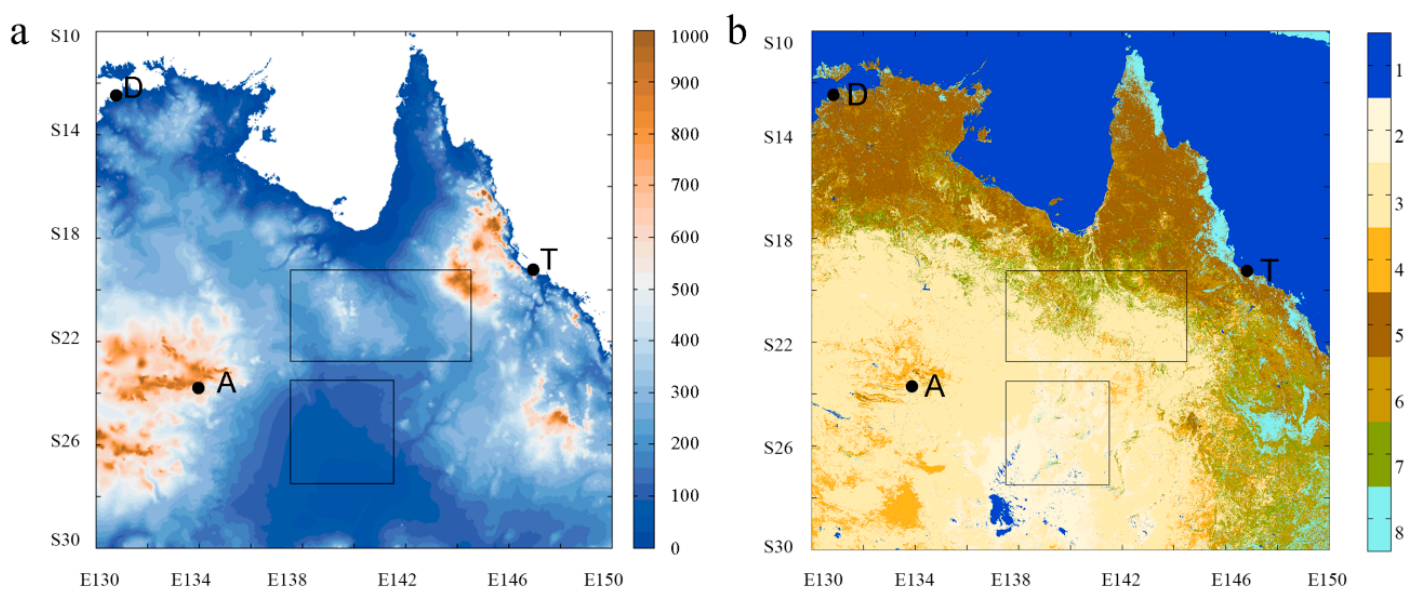

Figure 1. Topography (a) and land cover (b) over northeastern Australia (S10 $\left.{ }^{\circ}-\mathrm{S} 30^{\circ} ; \mathrm{E} 130^{\circ}-\mathrm{E} 150^{\circ}\right)$. Letters D, T, and A indicate the cities of Darwin, Townsville, and Alice Springs, respectively, which are identical in the following figures. The selected rectangular sub-region (REC, $\left(\mathrm{S} 19.25^{\circ}-\mathrm{S}_{2} 2.75^{\circ}\right.$; E137.5 $-\mathrm{E} 144.5^{\circ}$ ) covering about $28,340 \mathrm{~km}^{2}$ ) and square sub-region (SQU, $\left(\mathrm{S} 23.5^{\circ}-\mathrm{S} 27.5^{\circ}\right.$; E137. $5^{\circ}-E 141.5^{\circ}$ ) being about $17,892 \mathrm{~km}^{2}$ ) are illustrated. In (a) the DEM of GTOPO30 data is used, and statistical characteristics of elevation in REC and SQU sub-regions, including minimum, maximum, mean, and standard deviation, are $(87,1136,273,126)$ and $(44,202,87,25)$ meters above mean sea-level, respectively. In (b) land cover is based on GlobCover2009 data from European Space Agency GlobCover Portal. More detail of the legend is listed in Table 1.

\subsection{Datasets}

The satellite soil moisture product (ESA CCI soil moisture v. 0.20) was obtained from the European Space Agency Climate Change Initiative data portal (see http:/ / www.esa-soilmoisture-cci.org/) [22,32,33], and was generated by merging active and passive microwave observations [34,35]. This product covers 35 years (1978 to 2013) and is available at $0.25^{\circ}$ spatial resolution and a daily temporal resolution. Monthly data were obtained by time averaging the original daily product. A full data description and processing details are provided in Liu et al. [32]. As shown in Figure $1 \mathrm{~b}$ and Table 1 based on the GlobCover2009 data [36], the study region is primarily covered with sparse vegetation, which allows a high surface soil moisture retrieval accuracy of approximately $0.05 \mathrm{~m}^{3} \cdot \mathrm{m}^{-3}$ [37].

Table 1. Land cover types of Figure 1 and the percentages of sub-regions REC and SQU.

\begin{tabular}{clcc}
\hline Class \# & \multicolumn{1}{c}{ Class Name } & REC (\%) & SQU (\%) \\
\hline 1 & Water bodies & 0.03 & 0.70 \\
\hline 2 & Bare areas & 2.84 & 57.44 \\
\hline 3 & Sparse $(<15 \%)$ vegetation & 65.86 & 40.63 \\
\hline 4 & $\begin{array}{l}\text { Closed to open }(>15 \%) \text { herbaceous vegetation (grassland, } \\
\text { savannas, or lichens } / \text { mosses) }\end{array}$ & 2.49 & 0.33 \\
\hline 5 & $\begin{array}{l}\text { Closed to open }(>15 \%) \text { (broadleaved or needle-leaved, } \\
\text { evergreen or deciduous) shrubland }(<5 \text { m) }\end{array}$ & 6.19 & 0.01 \\
\hline 6 & Mosaic grassland $(50 \%-70 \%) /$ forest or shrubland $(20 \%-50 \%)$ & 7.24 & 0.03 \\
\hline 7 & Mosaic forest or shrubland $(50 \%-70 \%) /$ grassland $(20 \%-50 \%)$ & 14.96 & 0.24 \\
\hline 8 & Others & 0.39 & 0.62 \\
\hline
\end{tabular}


Daily and monthly precipitation data are obtained from the TRMM (Tropical Rainfall Measuring Mission) precipitation product (3B43, 3B42), ranging from January 1998 to the present at $0.25^{\circ}$ resolution [38]. These data have been shown to work well in Australia, adding information in locations with low densities of ground stations observing precipitation [39].

NDVI is used to describe vegetation conditions, which is a normalized ratio of (NIR - Red)/ (NIR + Red), where NIR and Red indicate the reflectance in the near-infrared and red spectral bands, respectively. NDVI is related to ecosystem production and widely used to indicate vegetation greenness [3,15]. Beck et al. [40] reported that the GIMMS (Global Inventory Modeling and Mapping Studies [10]) NDVI imagery from four AVHRR-derived NDVI datasets were best able to track temporal changes in Landsat samples and so these were used here. The NDVI data (NDVI3g version) from GIMMS [41] were averaged from $0.08^{\circ}$ to $0.25^{\circ}$ resolution at a monthly time step. These data cover 1981 onwards.

The three datasets overlap from 1998 while our case study is for 2009. Thus the period 1998-2009 was used to calculate monthly anomalies with the seasonal cycle removed. To directly demonstrate flood events, the MODIS (Moderate Resolution Imaging Spectroradiometer) open water likelihood (OWL) algorithm is applied at eight days and $1 \mathrm{~km}$ resolution and we use $6 \%$ as the threshold to identify surface water [42].

\subsection{Analysis Processing}

To characterize the data, the spatial and temporal patterns for a period of distinct differences between the precipitation, soil moisture, and responding vegetation growth (i.e., December 2008 to May 2009) are illustrated monthly. This period is selected as it represents exceptionally strong La Niña conditions that yielded high rainfall in eastern Australia due to positive teleconnections with the Indian Ocean Dipole and Southern Annular Mode [43,44]. This rainfall followed a decade-long drought in eastern Australia [45], so differences in fluvial-event vegetation growth and long-term (or residual) vegetation growth are maximized. After that, time series of regional averages are given. Then, a temporal autocorrelation analysis was applied on daily soil moisture and precipitation data to describe their temporal persistence. This analysis helps to explain different impacts from soil moisture and precipitation on water-limited vegetation dynamics.

Finally, the performance of reanalysis-forced soil moisture output from five state-of-the-art land surface models are evaluated for this northeastern Australia (December 2008 to May 2009) case study. The land surface models include: (i) ERA-Interim/Land [46]; and (ii) to (v) Global Land Data Assimilation System (GLDAS) models, specifically Community Land Model (CLM), Mosaic, Noah and Variable Infiltration Capacity (VIC) [47]. They all have multiple soil layers and only the surface layers not deeper than $10 \mathrm{~cm}$ are used for comparison (Table 2).

Table 2. The soil layers of five land surface models used in this study.

\begin{tabular}{cccc}
\hline Models & $\begin{array}{c}\text { Soil Layer Number(s) Considered Here } \\
\text { (Total Number of Soil Layers in the Model) }\end{array}$ & $\begin{array}{c}\text { Depth of Layers } \\
\text { Considered Here }\end{array}$ & Units \\
\hline ERA Interim/Land & $1(4)$ & $0-7 \mathrm{~cm}$ & $\mathrm{~m}^{3} / \mathrm{m}^{3}$ \\
CLM 2.0 & $1-3(10)$ & $0-9.1 \mathrm{~cm}$ & $\mathrm{~kg} / \mathrm{m}^{2}$ \\
Mosaic & $1(3)$ & $0-2 \mathrm{~cm}$ & $\mathrm{~kg} / \mathrm{m}^{2}$ \\
Noah & $1(4)$ & $0-10 \mathrm{~cm}$ & $\mathrm{~kg} / \mathrm{m}^{2}$ \\
VIC & $1(3)$ & $0-10 \mathrm{~cm}$ & $\mathrm{~kg} / \mathrm{m}^{2}$ \\
\hline
\end{tabular}

\section{Results}

Figure 2 illustrates monthly anomalies of precipitation, soil moisture, and NDVI from December 2008 to May 2009. In January 2009, strong positive precipitation anomalies in a triangular shape appeared in northeastern Australia (Figure 2(a2)). Soil moisture also showed strong positive anomalies with a similar spatial shape as the precipitation anomalies (Figure 2(b2)). However, NDVI did not 
show a clear and spatially consistent anomaly (Figure 2(c2)), suggesting that the response of vegetation to water supply was delayed, and/or that standing water suppressed the NDVI signal. In February, while the positive precipitation anomalies disappeared (Figure 2(a3)), the positive soil moisture anomalies first observed in January persisted into February (Figure 2(b3)). Distinct positive NDVI anomalies now appeared clearly in the areas where those of soil moisture persisted (Figure 2(c3)), illustrating a delayed vegetation response to precipitation via soil moisture persistence. The strongest NDVI anomalies appeared in February. In the following months (March-May 2009), there was little precipitation (Figure 2(a4-a6)), and the soil moisture anomalies persisted with a low continuous decay (Figure 2(b4-b6)). During this period, NDVI anomalies exhibited a similar decay to soil moisture (Figure 2(c4-c6)).
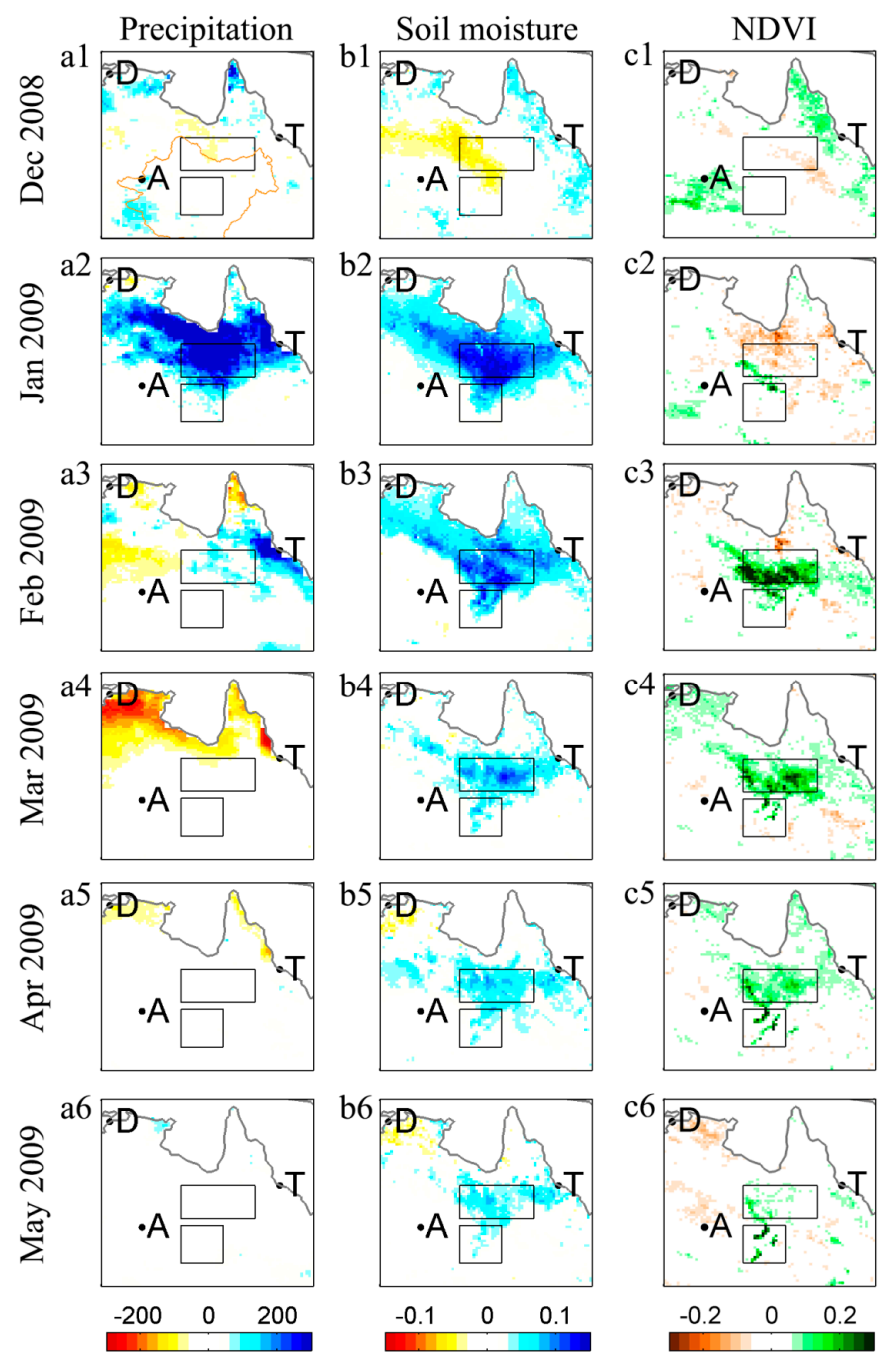

Figure 2. (a1-a6) Monthly anomalies of gridded precipitation (left column of panels, $\mathrm{mm} \cdot \mathrm{month}^{-1}$ ), (b1-b6) satellite soil moisture (middle column of panels, $\mathrm{m}^{3} \cdot \mathrm{m}^{-3}$ ) and (c1-c6) NDVI (right column of panels, unitless) from December 2008 to May 2009. All are at $0.25^{\circ}$ spatial resolution. The Lake Eyre Basin boundary is illustrated in subplot a1 (orange line).

The detailed spatial-temporal patterns in sub-region SQU further demonstrate the different impacts of precipitation and soil moisture on NDVI (Figure 2). The flood extent was identified using MODIS OWL data (Figure 3). Surface water in this area mainly occurred after 17 January 2009 (Figure 3). There were no distinct precipitation events during February-May 2009 (Figure 2(a3-a6)). In contrast, due to lateral inflow into the SQU sub-region, both soil moisture and NDVI showed clear 
positive anomalies, with the spatial patterns of soil moisture and NDVI anomalies in SQU evolving in a similar manner (Figure 2(b2-b6,c2-c6)). In February 2009, a structure of two zonal intensive areas in soil moisture anomalies occurred in the SQU region (Figure 2(b3)). Similarly, two zonal intensive areas of NDVI anomalies were observed in March 2009 (Figure 2(c4)). In March 2009, soil moisture anomalies reached to the south edge of the SQU sub-region and lasted at least through April of 2009 (Figure 2(b4,b5)). NDVI anomalies also reached the SQU sub-region's south edge during April and May 2009 (Figure 2(c5,c6)). None of these February-May 2009 patterns were found in the precipitation anomalies (Figure 2(a3-a6)).
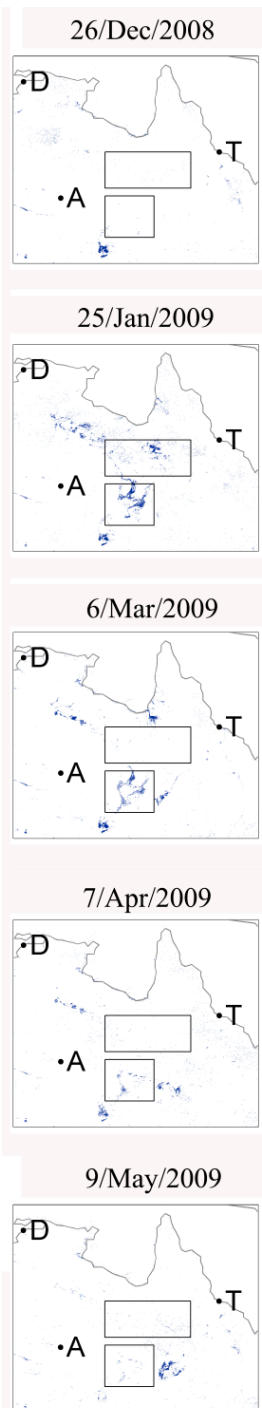
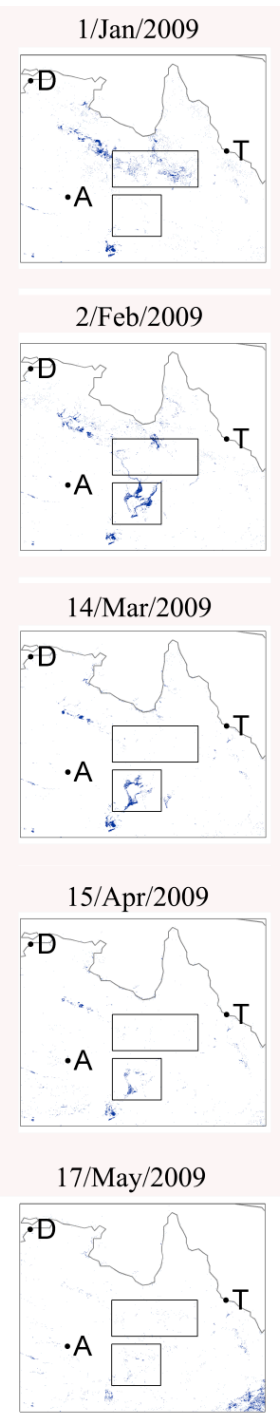
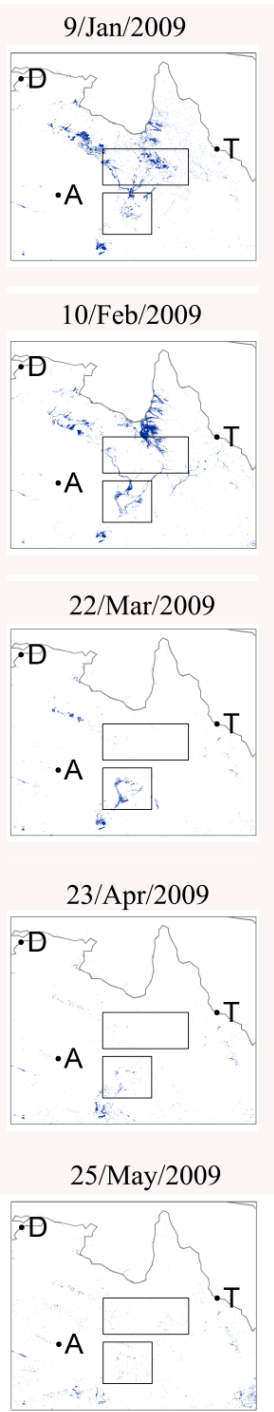
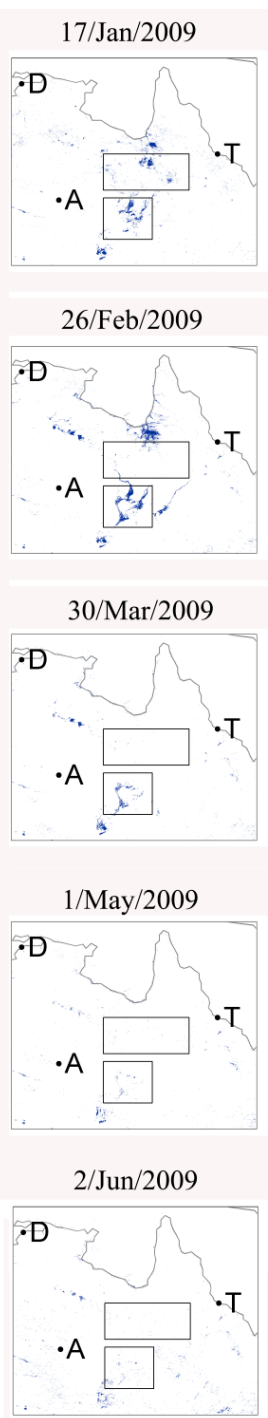

Figure 3. Mapping of surface water using the MODIS Open Water Likelihood (OWL) product from 26 December 2008 to 2 June 2009 using a threshold of 6\%. Data in 18 February 2009 is not available due to cloud contamination.

The seasonal patterns of the REC and SQU sub-regions are illustrated in Figure 4. Temporal patterns of precipitation over both sub-regions are similar, with clear rainy and dry seasons. Precipitation peaks in January, although the amounts received in these two sub-regions are quite different (Figure 4a,b). Precipitation, soil moisture, and NDVI over REC exhibit coherent seasonal patterns on average over 1998-2009. Precipitation precedes soil moisture and soil moisture precedes NDVI, each by about one month. For the SQU sub-region, soil moisture and NDVI have similar 
patterns; however, they are both different from those of precipitation. This result is similar to that shown in Figure 2, where NDVI had more similar spatio-temporal patterns with soil moisture rather than precipitation (Figure 4c-f). It is relevant to note that the NDVI and soil moisture products we use here are completely independent.

REC
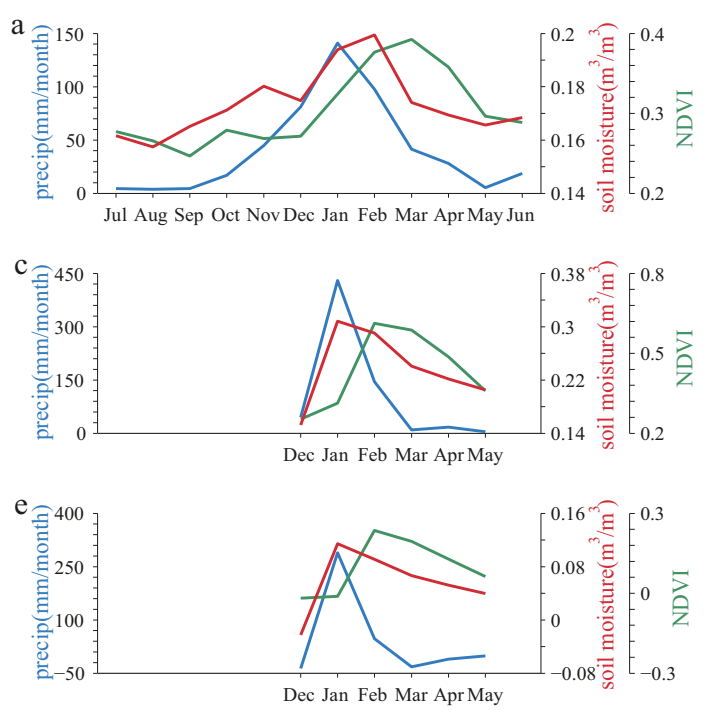

SQU
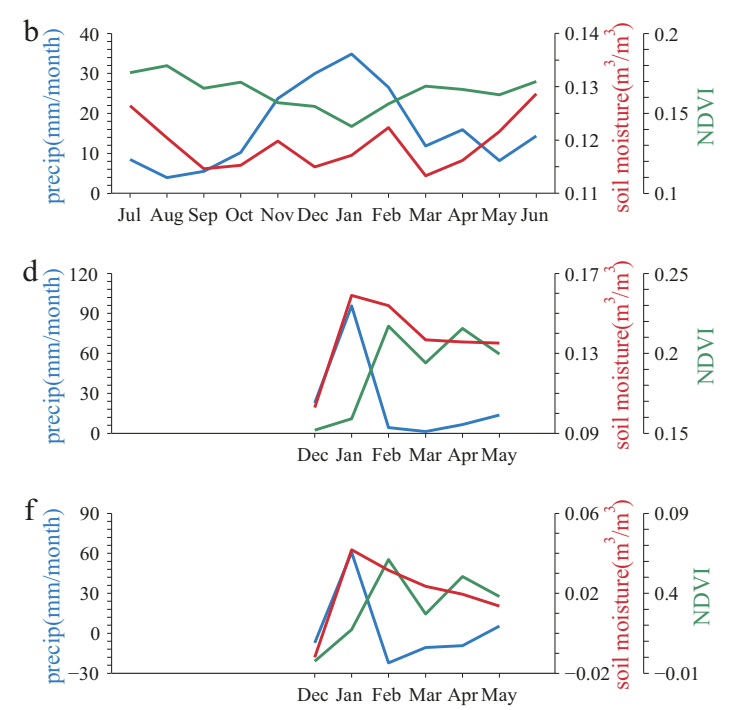

Figure 4. Seasonal patterns of precipitation ( $\mathrm{mm} / \mathrm{month}$, blue), soil moisture $\left(\mathrm{m}^{3} / \mathrm{m}^{3}\right.$, red), and NDVI (unitless, green) over sub-regions REC (left column of panels) and SQU (right column of panels). The locations of these two sub-regions are shown on Figure 1. Long-term 1998-2009 monthly averages are illustrated in subplots (a,b). The case period (December 2008-May 2009) monthly series of original data are shown in subplots $(\mathbf{c}, \mathbf{d})$, and anomalies are shown in subplots $(\mathbf{e}, \mathbf{f})$, respectively. Note the different units of the Y-axes between the REC and SQU cases.

Figure 5 illustrates the daily temporal autocorrelations of precipitation and soil moisture for the REC sub-region (see Materials and Methods). Assessed by autocorrelation, soil moisture has a much longer memory than precipitation, lasting about three months. In contrast, within a single week, the autocorrelation of precipitation loses significance $(p=0.05)$. The autocorrelation e-folding $(1 / \mathrm{e})$ time scales [46] of soil moisture and precipitation are 10 days and one day, respectively.
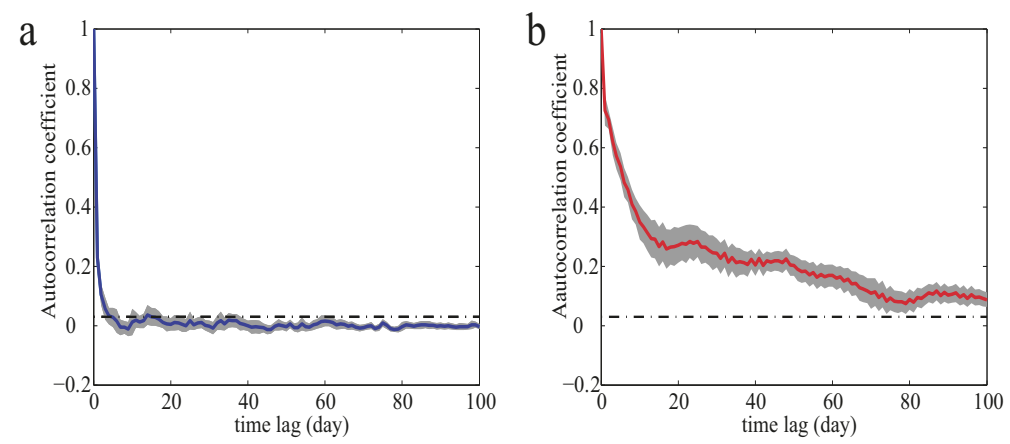

Figure 5. Autocorrelation graphs of (a) daily TRMM precipitation (blue) and (b) satellite soil moisture (red) during 1998-2009 over sub-region REC (see Figure 1). Blue and red lines are the averages of autocorrelations in REC sub-region with standard deviations indicated by gray areas. Black dash-dot horizontal lines indicate where $p=0.05$ using the Student's $t$-test. 
Soil moisture anomalies from remotely sensed and model outputs of this northeastern Australia case study from December 2008 to May 2009 are provided in Figure 6. ERA Interim/Land simulates the spatial pattern of soil moisture anomalies best from January 2009 to February 2009. However, all models fail to capture the length of soil moisture memory except the VIC model, which has the most unrealistic spatial pattern. Almost no signal is found in the SQU sub-region and this is likely caused by the lack of flood processes in these models, revealing the need for and strength of soil moisture observation over soil moisture model output.
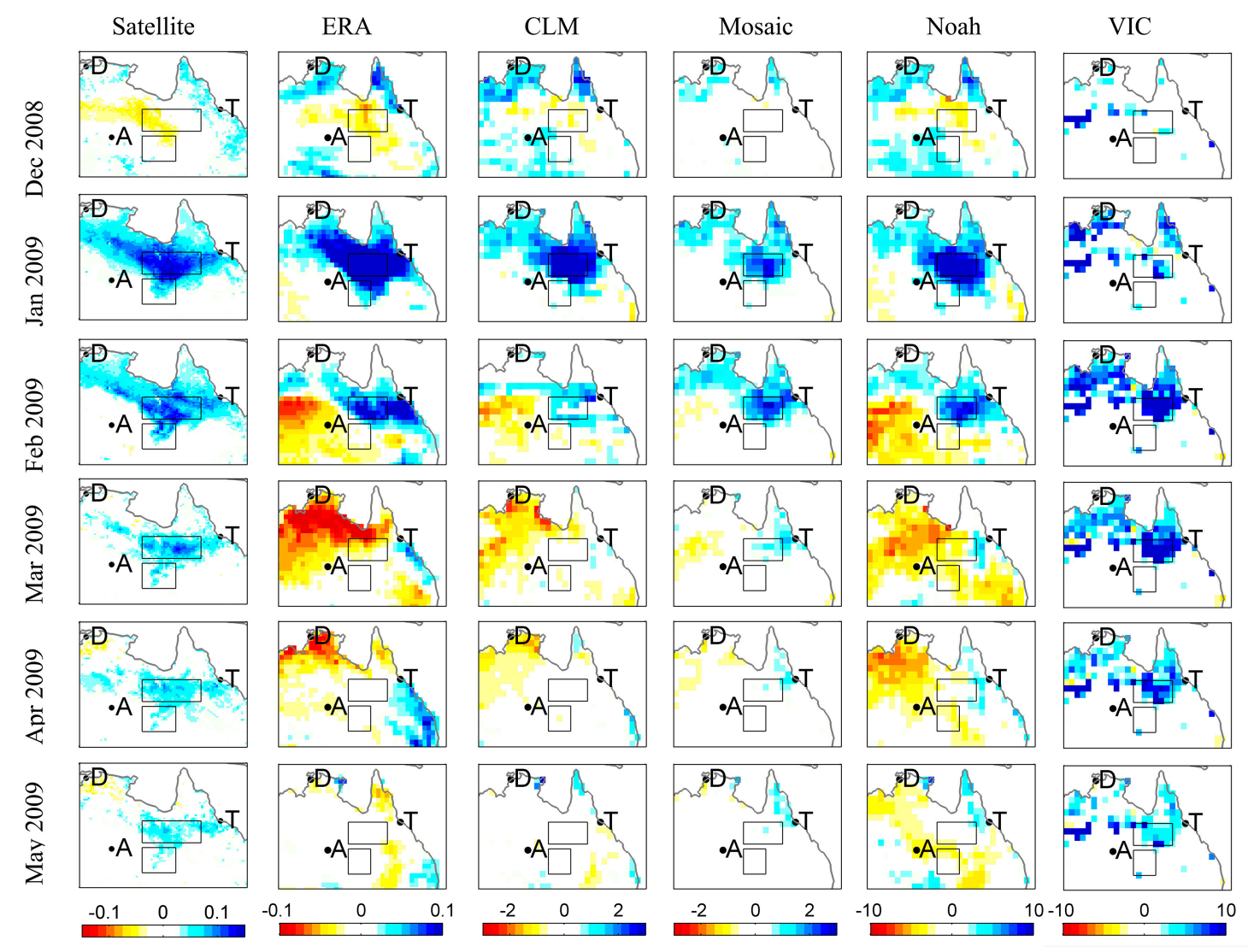

Figure 6. Similar to Figure 2 with results from satellite soil moisture, ERA Interim/Land, and GLDAS models (CLM, Mosaic, Noah, and VIC) shown in the columns from left to right. See the codes at the top of each column of panels. The unit of ERA Interim/Land soil moisture is $\mathrm{m}^{3} / \mathrm{m}^{3}$, and GLDAS models use the unit of $\mathrm{kg} / \mathrm{m}^{2}$. The scale differences are mainly caused by the depth variations (see Materials and Methods, specifically Table 2).

\section{Discussion}

Water availability is a primary constraint on vegetation dynamics besides temperature and radiation [3]. Although soil moisture is a more direct variable governing water-limited vegetation dynamics then precipitation, previously the availability of reliable regional soil moisture data has limited its application. By examining a case where lateral inflow was the primary cause of soil moisture increase, as opposed to precipitation received over the landscape, we clearly demonstrated the advantages of using satellite soil moisture rather than gridded precipitation products or land surface model output to assess vegetation dynamics.

In the case presented here, the temporal scale of the delayed vegetation response to soil moisture is about one month. It is, however, difficult to determine a typical time scale for the delayed vegetation response to precipitation, because the NDVI anomalies during February to May 2009 were all related to precipitation anomalies in January 2009 and subsequent lateral inflow (Figure 2). Previous studies 
have found that the NDVI response to precipitation has a "saturation" effect, i.e., NDVI is not sensitive to precipitation once precipitation exceeds some thresholds [12,14]. In other words, once soil is saturated at water holding capacity, more precipitation will only cause more runoff and/or the moisture exceeding the threshold is stored in the deeper soil layers beyond the depth of the recently established root zone (in the case of a recurrent flush of growth following precipitation events in water-limited environments [9]).

Therefore, the threshold of precipitation varies with soil properties. Monitoring soil moisture directly overcomes this issue. On the other hand, if flooding occurs, the lateral overland inflow cannot be detected by monitoring precipitation only. In our case, soil moisture anomalies in the SQU sub-region are driven by lateral inflows and positive precipitation anomalies did not occur there. As shown in Figure 2, this is a lateral inflow receiving area and, in consequence, positive NDVI anomalies were observed as vegetation responds to increased water supply, and this conclusion relies solely on the use of soil moisture data.

As shown in Figure 5, soil moisture has a much longer memory than precipitation, which has a rather short memory up to a few days; therefore, the triangular precipitation anomalies in January, although strong, did not persist into February (Figures 2 and 4). Such a persistence of soil moisture anomalies (Figures 2 and 4) was detected because soil moisture exhibits a strong autocorrelation up to about three months (Figure 5). The soil moisture memory will rely on the soil properties [48]; as usual, clay-rich soils have a high water holding capacity. Figure 7 demonstrates the distribution of vertisols [49], a type of clay-rich soils that can swell when wet. The spatial patterns of vertisols and soil moisture are coherent. Particularly, the two zonal intensive areas of soil moisture and NDVI in SQU sub-region from February to May 2009 (see Figure 2(b3-b6,c3-c6)) are related to the vertisols' distribution in this sub-region (Figure 7). The surface water (Figure 3) also has a similar structure from January to March 2009, indicating coherent distributions of river network and vertisols. Thereby, river network and soil properties also play an important role in this study.

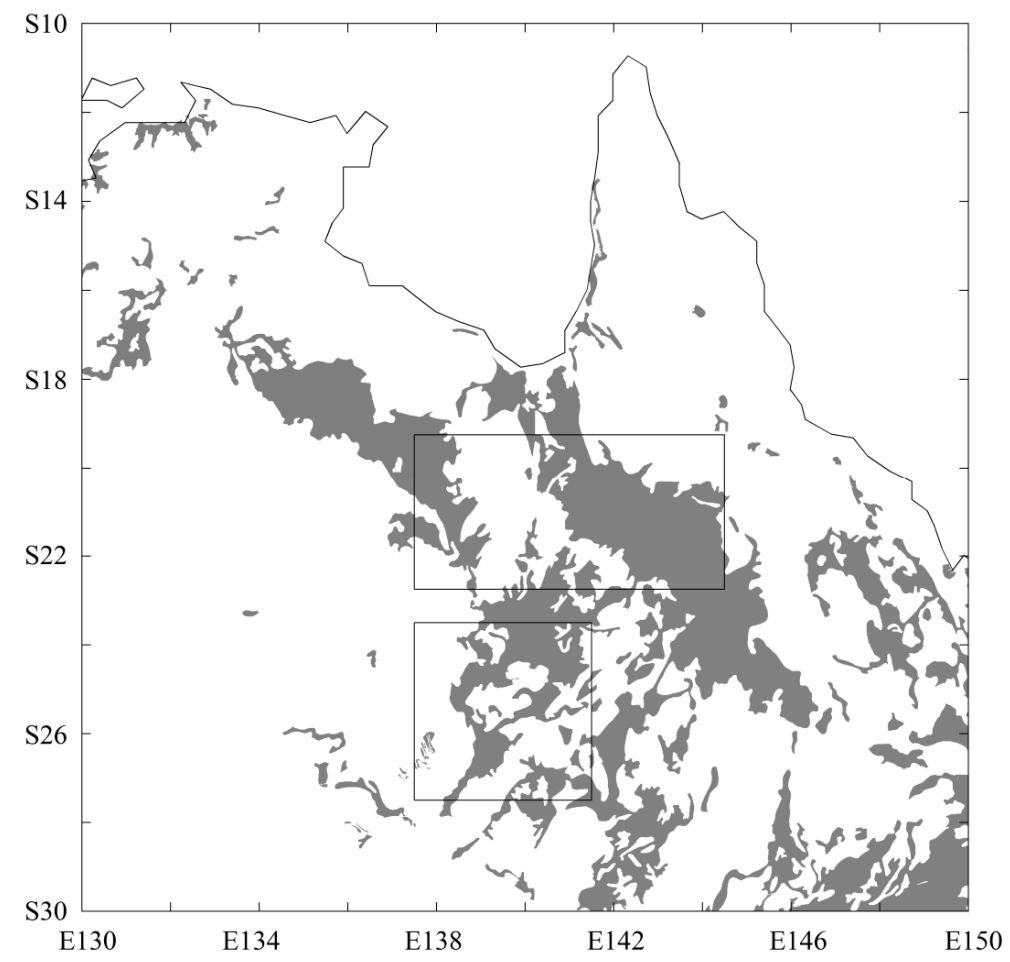

Figure 7. Location of vertisols for the study region based on Harmonized World Soil Database. Vertisols cover $50.2 \%$ and $37.3 \%$ of the REC and SQU sub-regions, respectively. 
Four of the five selected land surface models underestimated the memory length of soil moisture, and all five models failed to represent the soil moisture anomalies over the lateral inflow receiving SQU sub-region (Figure 6). A potential reason is their lack of water transport process in the models.

Therefore, monitoring soil moisture directly will bring new information in addition to precipitation, particularly for lateral inflow and/or clay-rich regions. This study can be used as a benchmark to evaluate vegetation's response to water supply in models, emphasizing the use of soil moisture in future water-related terrestrial carbon cycle studies. The present case study could act as a benchmarking case to evaluate land surface model performance in subsequent studies.

\section{Conclusions}

In a direct regional comparison between satellite remotely sensed soil moisture and gridded precipitation (and land surface models) of water-related vegetation dynamics, this paper demonstrated that satellite remotely sensed soil moisture was superior to precipitation (and land surface models) to assess vegetation dynamics in a large lateral inflow receiving area in northeastern Australia. We illustrated that vegetation spatial-temporal patterns follow remotely sensed soil moisture much closer than precipitation. Remotely sensed soil moisture has a long memory of several months and the memory length was underestimated in four of five selected land surface models. Previous studies demonstrated the difficulty to determine a typical time scale of the vegetation response to precipitation and the "saturation" phenomenon (NDVI is not sensitive to precipitation once precipitation exceeds some thresholds). These two issues are mainly caused by the fact that a comparison of precipitation and NDVI does not take the soil properties into account. This was improved by employing soil moisture in the present analysis. Monitoring soil moisture can help to predict the changes of vegetation in similar water-limited regions worldwide. This case study provides robust direct evidence to support the fact that the vegetation dynamics of water-limited ecosystems are better described at a large scale by remotely sensed soil moisture than by precipitation or land surface models.

Acknowledgments: Tiexi Chen, Xing Chen, and Guojie Wang acknowledge the support from the National Key Basic Research Program of China (2010CB428506) and the National Natural Science Foundation of China (Grants 31570464, 41321062, 41375099, 41561124014 and 91337108). Tiexi Chen and Guojie Wang acknowledge the support from the "scientific research startup fund (Grants. 2241021301065 and 2241051301004)" of Nanjing University of Information Science and Technology, and the 'Outstanding Ph.D. candidate' program of Nanjing University. Yi Y. Liu was the recipient of an Australian Research Council Discovery Early Career Researcher Award (DECRA) Fellowship (project number DE140100200). We thank Catherine Ticehurst for the help with MODIS OWL data. The work of Richard A. M. de Jeu has been undertaken as part of the ESA CCI for soil moisture (http://www.esa-soilmoisture-cci.org/), contract No. 4000104814/11/I-NB). Fangmin Zhang acknowledges the National Natural Science Foundation of China (31300420) and the Natural Science Foundation of Jiangsu (BK20130987).

Author Contributions: Tiexi Chen, Tim R. McVicar, and Xing Chen conceived the study. Tiexi Chen and Hong Shen conducted the primary data analysis. All authors discussed the results and implications and commented on the manuscript.

Conflicts of Interest: The authors declare no conflict of interest.

\section{References}

1. Zeng, N.; Neelin, J.D.; Lau, K.M.; Tucker, C.J. Enhancement of interdecadal climate variability in the Sahel by vegetation interaction. Science 1999, 286, 1537-1540. [CrossRef] [PubMed]

2. Heimann, M.; Reichstein, M. Terrestrial ecosystem carbon dynamics and climate feedbacks. Nature 2008, 451, 289-292. [CrossRef] [PubMed]

3. Nemani, R.R.; Keeling, C.D.; Hashimoto, H.; Jolly, W.M.; Piper, S.C.; Tucker, C.J.; Myneni, R.B.; Running, S.W. Climate-driven increases in global terrestrial Net Primary Production from 1982 to 1999. Science 2003, 300, 1560-1563. [CrossRef] [PubMed]

4. Piao, S.L.; Wang, X.H.; Ciais, P.; Zhu, B.; Wang, T.; Liu, J. Changes in satellite-derived vegetation growth trend in temperate and boreal Eurasia from 1982 to 2006. Glob. Chang. Biol. 2011, 17, 3228-3239. [CrossRef] 
5. Herrmann, S.M.; Anyamba, A.; Tucker, C.J. Recent trends in vegetation dynamics in the African Sahel and their relationship to climate. Glob. Environ. Chang. 2005, 15, 394-404. [CrossRef]

6. Hickler, T.; Eklundh, L.; Seaquist, J.W.; Smith, B.; Ardo, J.; Olsson, L.; Sykes, M.T.; Sjostrom, M. Precipitation controls Sahel greening trend. Geophys. Res. Lett. 2005, 32. [CrossRef]

7. Huber, S.; Fensholt, R.; Rasmussen, K. Water availability as the driver of vegetation dynamics in the African Sahel from 1982 to 2007. Glob. Planet. Chang. 2011, 76, 186-195. [CrossRef]

8. Rodriguez-Iturbe, I. Ecohydrology: A hydrologic perspective of climate-soil-vegetation dynamies. Water Resour. Res. 2000, 36, 3-9. [CrossRef]

9. McVicar, T.R.; Jupp, D.L.B. The current and potential operational uses of remote sensing to aid decisions on drought exceptional circumstances in Australia: A review. Agric. Syst. 1998, 57, 399-468. [CrossRef]

10. Tucker, C.J.; Pinzon, J.E.; Brown, M.E.; Slayback, D.A.; Pak, E.W.; Mahoney, R.; Vermote, E.F.; El Saleous, N. An extended AVHRR 8-km NDVI dataset compatible with MODIS and SPOT vegetation NDVI data. Int. J. Remote Sens. 2005, 26, 4485-4498. [CrossRef]

11. Wang, J.; Rich, P.M.; Price, K.P. Temporal responses of NDVI to precipitation and temperature in the central Great Plains, USA. Int. J. Remote Sens. 2003, 24, 2345-2364. [CrossRef]

12. Gessner, U.; Naeimi, V.; Klein, I.; Kuenzer, C.; Klein, D.; Dech, S. The relationship between precipitation anomalies and satellite-derived vegetation activity in central Asia. Glob. Planet. Chang. 2013, 110 Pt A, $74-87$. [CrossRef]

13. Cañón, J.; Domínguez, F.; Valdes, J.B. Vegetation responses to precipitation and temperature: A spatiotemporal analysis of ecoregions in the Colorado River Basin. Int. J. Remote Sens. 2011, 32, 5665-5687. [CrossRef]

14. Nicholson, S.E.; Farrar, T.J. The influence of soil type on the relationships between NDVI, rainfall, and soil-moisture in semiarid Botswana.1. NDVI response to rainfall. Remote Sens. Environ. 1994, 50, 107-120. [CrossRef]

15. Lotsch, A.; Friedl, M.A.; Anderson, B.T.; Tucker, C.J. Coupled vegetation-precipitation variability observed from satellite and climate records. Geophys. Res. Lett. 2003, 30. [CrossRef]

16. Donohue, R.J.; Roderick, M.L.; McVicar, T.R.; Farquhar, G.D. Impact of $\mathrm{CO}_{2}$ fertilization on maximum foliage cover across the globe's warm, arid environments. Geophys. Res. Lett. 2013, 40, 3031-3035. [CrossRef]

17. Chen, T.; Werf, G.R.; Jeu, R.A.M.; Wang, G.; Dolman, A.J. A global analysis of the impact of drought on Net Primary Productivity. Hydrol. Earth Syst. Sci. 2013, 17, 3885-3894. [CrossRef]

18. De Jeu, R.A.M.; Holmes, T.R.H.; Parinussa, R.M.; Owe, M. A spatially coherent global soil moisture product with improved temporal resolution. J. Hydrol. 2014, 516, 284-296. [CrossRef]

19. Entekhabi, D.; Njoku, E.G.; Neill, P.E.; Kellogg, K.H.; Crow, W.T.; Edelstein, W.N.; Entin, J.K.; Goodman, S.D.; Jackson, T.J.; Johnson, J.; et al. The soil moisture active passive (SMAP) mission. IEEE Proc. 2010, 98, 704-716. [CrossRef]

20. Kerr, Y.H.; Waldteufel, P.; Richaume, P.; Wigneron, J.P.; Ferrazzoli, P.; Mahmoodi, A.; Al Bitar, A.; Cabot, F.; Gruhier, C.; Juglea, S.E. The SMOS soil moisture retrieval algorithm. IEEE Trans. Geosci. Remote Sens. 2012, 50, 1384-1403. [CrossRef]

21. Dorigo, W.; de Jeu, R.; Chung, D.; Parinussa, R.; Liu, Y.; Wagner, W.; Fernandez-Prieto, D. Evaluating global trends (1988-2010) in harmonized multi-satellite surface soil moisture. Geophys. Res. Lett. 2012, 39. [CrossRef]

22. Liu, Y.Y.; Dorigo, W.A.; Parinussa, R.M.; de Jeu, R.A.M.; Wagner, W.; McCabe, M.F.; Evans, J.P.; van Dijk, A.I.J.M. Trend-preserving blending of passive and active microwave soil moisture retrievals. Remote Sens. Environ. 2012, 123, 280-297. [CrossRef]

23. Rebel, K.T.; de Jeu, R.A.M.; Ciais, P.; Viovy, N.; Piao, S.L.; Kiely, G.; Dolman, A.J. A global analysis of soil moisture derived from satellite observations and a land surface model. Hydrol. Earth Syst. Sci. 2012, 16, 833-847. [CrossRef]

24. Yuan, X.; Ma, Z.G.; Pan, M.; Shi, C.X. Microwave remote sensing of short-term droughts during crop growing seasons. Geophys. Res. Lett. 2015, 42, 4394-4401. [CrossRef]

25. Al-Yaari, A.; Wigneron, J.-P.; Ducharne, A.; Kerr, Y.; De Rosnay, P.; De Jeu, R.; Govind, A.; Al Bitar, A.; Albergel, C.; Munoz-Sabater, J.; et al. Global-scale evaluation of two satellite-based passive microwave soil moisture datasets (SMOS and AMSR-E) with respect to land data assimilation system estimates. Remote Sens. Environ. 2014, 149, 181-195. [CrossRef] 
26. Leroux, D.J.; Kerr, Y.H.; Richaume, P.; Fieuzal, R. Spatial distribution and possible sources of SMOS errors at the global scale. Remote Sens. Environ. 2013, 133, 240-250. [CrossRef]

27. Rüdiger, C.; Calvet, J.-C.; Gruhier, C.; Holmes, T.R.; De Jeu, R.A.; Wagner, W. An intercomparison of ERS-Scat and AMSR-E soil moisture observations with model simulations over France. J. Hydrometeorol. 2009, 10, 431-447. [CrossRef]

28. Chen, T.; de Jeu, R.A.M.; Liu, Y.Y.; van der Werf, G.R.; Dolman, A.J. Using satellite based soil moisture to quantify the water driven variability in NDVI: A case study over mainland Australia. Remote Sens. Environ. 2014, 140, 330-338. [CrossRef]

29. Jarihani, A.A.; Callow, J.N.; McVicar, T.R.; Van Niel, T.G.; Larsen, J.R. Satellite-derived Digital Elevation Model (DEM) selection, preparation and correction for hydrodynamic modelling in large, low-gradient and data-sparse catchments. J. Hydrol. 2015, 524, 489-506. [CrossRef]

30. Jarihani, A.A.; Larsen, J.R.; Callow, J.N.; McVicar, T.R.; Johansen, K. Where does all the water go? Partitioning water transmission losses in a data-sparse, multi-channel and low-gradient dryland river system using modelling and remote sensing. J. Hydrol. 2015, 529, 1511-1529. [CrossRef]

31. USGS. Global 30 Arc-Second Elevation (GTOPO30). 1996. Available online: https://lta.cr.usgs.gov/ GTOPO30 (accessed on 8 January 2015).

32. Liu, Y.Y.; Parinussa, R.M.; Dorigo, W.A.; De Jeu, R.A.M.; Wagner, W.; van Dijk, A.I.J.M.; McCabe, M.F.; Evans, J.P. Developing an improved soil moisture dataset by blending passive and active microwave satellite-based retrievals. Hydrol. Earth Syst. Sci. 2011, 15, 425-436. [CrossRef]

33. Wagner, W.; Dorigo, W.; de Jeu, R.; Fernandez, D.; Benveniste, J.; Haas, E.; Ertl, M. Fusion of active and passive microwave observations to create an essential climate variable data record on soil moisture. In Proceedings of the XXII International Society for Photogrammetry and Remote Sensing (ISPRS) Congress, Melbourne, Australia, 25 August-1 September 2012.

34. De Jeu, R.A.M.; Wagner, W.; Holmes, T.R.H.; Dolman, A.J.; van de Giesen, N.C.; Friesen, J. Global soil moisture patterns observed by space borne microwave radiometers and scatterometers. Surv. Geophys. 2008, 29, 399-420. [CrossRef]

35. Wagner, W.; Lemoine, G.; Rott, H. A method for estimating soil moisture from ERS scatterometer and soil data. Remote Sens. Environ. 1999, 70, 191-207. [CrossRef]

36. Bontemps, S.; Defourny, P.; Bogaert, E.V.; Arino, O.; Kalogirou, V.; Perez, J.R. Globcover 2009-Products Description and Validation Report. 2011. Available online: http://due.esrin.esa.int/page_globcover.php (accessed on 2 Feburay 2015).

37. Parinussa, R.M.; Meesters, A.G.; Liu, Y.Y.; Dorigo, W.; Wagner, W.; De Jeu, R.A. Error estimates for near-real-time satellite soil moisture as derived from the land parameter retrieval model. IEEE Geosci. Remote Sens. Lett. 2011, 8, 779-783. [CrossRef]

38. Huffman, G.J.; Bolvin, D.T.; Nelkin, E.J.; Wolff, D.B.; Adler, R.F.; Gu, G.; Hong, Y.; Bowman, K.P.; Stocker, E.F. The TRMM multisatellite precipitation analysis (TMPA): Quasi-global, multiyear, combined-sensor precipitation estimates at fine scales. J. Hydrometeorol. 2007, 8, 38-55. [CrossRef]

39. Chappell, A.; Renzullo, L.J.; Raupach, T.H.; Haylock, M. Evaluating geostatistical methods of blending satellite and gauge data to estimate near real-time daily rainfall for Australia. J. Hydrol. 2013, 493, 105-114. [CrossRef]

40. Beck, H.E.; McVicar, T.R.; van Dijk, A.I.J.M.; Schellekens, J.; de Jeu, R.A.M.; Bruijnzeel, L.A. Global evaluation of four AVHRR-NDVI data sets: Intercomparison and assessment against Landsat imagery. Remote Sens. Environ. 2011, 115, 2547-2563. [CrossRef]

41. Pinzon, J.E.; Tucker, C.J. A non-stationary 1981-2012 AVHRR NDVI3g time series. Remote Sens. 2014, 6, 6929-6960. [CrossRef]

42. Ticehurst, C.; Guerschman, J.; Chen, Y. The strengths and limitations in using the daily MODIS open water likelihood algorithm for identifying flood events. Remote Sens. 2014, 6, 11791-11809. [CrossRef]

43. Boschat, G.; Pezza, A.; Simmonds, I.; Perkins, S.; Cowan, T.; Purich, A. Large scale and sub-regional connections in the lead up to summer heat wave and extreme rainfall events in eastern Australia. Clim. Dyn. 2015, 44, 1823-1840. [CrossRef]

44. Fasullo, J.T.; Boening, C.; Landerer, F.W.; Nerem, R.S. Australia's unique influence on global sea level in 2010-2011. Geophys. Res. Lett. 2013, 40, 4368-4373. [CrossRef] 
45. Dijk, A.I.; Beck, H.E.; Crosbie, R.S.; Jeu, R.A.; Liu, Y.Y.; Podger, G.M.; Timbal, B.; Viney, N.R. The millennium drought in southeast Australia (2001-2009): Natural and human causes and implications for water resources, ecosystems, economy, and society. Water Resour. Res. 2013, 49, 1040-1057. [CrossRef]

46. Balsamo, G.; Albergel, C.; Beljaars, A.; Boussetta, S.; Brun, E.; Cloke, H.; Dee, D.; Dutra, E.; Muñoz-Sabater, J.; Pappenberger, F.; et al. ERA-Interim/Land: A global land surface reanalysis data set. Hydrol. Earth Syst. Sci. 2015, 19, 389-407. [CrossRef]

47. Rodell, M.; Houser, P.R.; Jambor, U.; Gottschalck, J.; Mitchell, K.; Meng, C.J.; Arsenault, K.; Cosgrove, B.; Radakovich, J.; Bosilovich, M.; et al. The global land data assimilation system. Bull. Am. Meteorol. Soc. 2004, 85, 381-394. [CrossRef]

48. Liu, Y.Y.; Evans, J.P.; McCabe, M.F.; de Jeu, R.A.M.; van Dijk, A.; Su, H. Influence of cracking clays on satellite estimated and model simulated soil moisture. Hydrol. Earth Syst. Sci. 2010, 14, 979-990. [CrossRef]

49. FAO/IIASA/ISRIC/ISSCAS/JRC. Harmonized World Soil Database (Version 1.2); FAO: Rome, Italy; IIASA: Laxenburg, Austria, 2012.

(C) 2016 by the authors; licensee MDPI, Basel, Switzerland. This article is an open access article distributed under the terms and conditions of the Creative Commons Attribution (CC-BY) license (http://creativecommons.org/licenses/by/4.0/). 